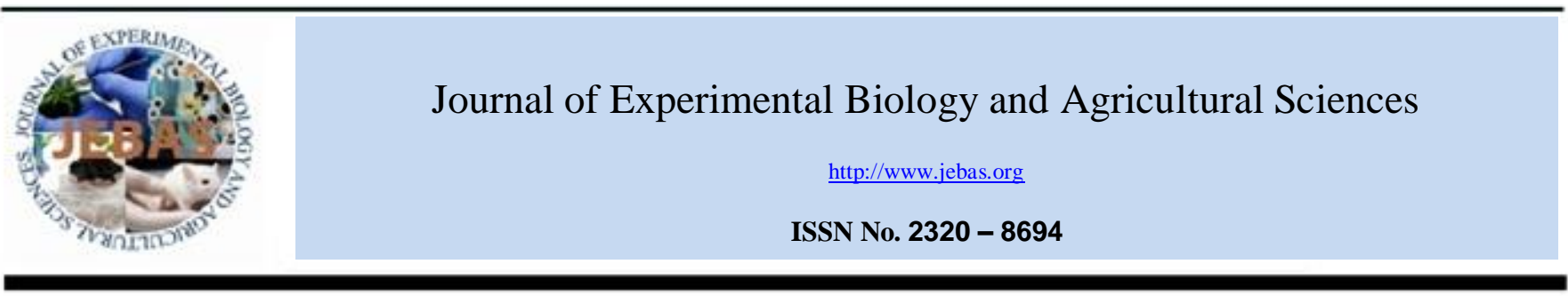

\title{
THE INSECT PATHOGENIC FUNGUS Verticillium lecanii (Zimm.) Viegas AND ITS USE FOR PESTS CONTROL: A REVIEW
}

\author{
Thiery B C ALAVO
}

Laboratoire d'Entomologie Appliquée, Faculté des Sciences et Techniques, Université d'Abomey Calavi; BP 215 Godomey (Bénin).

Received - May 05, 2015; Revision - May 16, 2015; Accepted - July 30, 2015

Available Online - August 20, 2015

DOI: http://dx.doi.org/10.18006/2015.3(4).337.345

\author{
KEYWORDS \\ Bio-control \\ Entomopathogenic fungi \\ Verticillium lecanii \\ Crop Protection
}

\begin{abstract}
Chemical insecticides play an important role in the control of plant damage and plant diseases. However, extensive use of these products has led to the disruption of ecosystems because of several reasons such as death of non-target species, accumulation of pesticide residues in the environment and food, and buildup of pesticide resistance in the target species. Biological control is one of the alternatives to chemical pesticides and it can be described as the limitation of the abundance of living organisms and their products by other living organisms. Predators, parasitoids, fungi and other beneficial organisms can be used for the biocontrol of insect pests. The fungus Verticillium lecanii is one of the members of Deuteromycetes and it can be used for crop protection. This paper is a review of the international literature related to $V$. lecanii for the bio-control of insects of agricultural importance.
\end{abstract}

* Corresponding author

E-mail: thieryalavo@hotmail.com (Thiery B C ALAVO)

Peer review under responsibility of Journal of Experimental Biology and Agricultural Sciences.

Production and Hosting by Horizon Publisher (www.myvision.webs.com/horizon.html).

All rights reserved.
All the article published by Journal of Experimental Biology and Agricultural Sciences is licensed under a Creative Commons Attribution-NonCommercial 4.0 International License Based on a work at www.jebas.org.

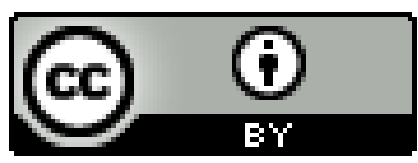




\section{Introduction}

Chemical pest control occupies an important place among the plant protection methods. Before World War II, chemical pest control was mainly restricted to the application of nicotine and some arsenical products (Schepers, 1989). Sprayed on the crops, they kill the pests that come into contact with these compounds, but they have neither systemic nor residual effects. Since the war, chemical control of insects has made rapid progress, starting with the development of DDT formulations and other chlorinated hydrocarbons such as lindane, which showed a residual effect but had no systemic properties (Schepers, 1989).

The persistence of residues of the chlorinated hydrocarbons causes accumulation in the food chain and since this phenomenon has become known, unrestrained application of those products no longer seems justified and is already prohibited in many countries. The development of systemic insecticides starting with the formulation of organophosphorous compounds, opened new perspectives in pests control (Schepers, 1989). Later, the carbamate insecticides added more possibilities, as did the development of synthetic pyrethroids. All these products played an invaluable role in the control of plant damage and plant diseases (Schepers, 1989). However, extensive use of chemical insecticides has led to the disruption of ecosystems because of the death of non-target species, the accumulation of pesticide residues in the environment and food, and the build up of pesticide resistance in the target species (FAO, 1989; Devonshire, 1989).

Biological control can be described as the limitation of the abundance of living organisms and their products by other living organisms. The term encompasses both the biotic component of natural control, which is, the naturally occurring regulation of the numbers of a species by the action of its natural enemies, and also, applied or manipulative biological control, which is the use by man of biological means to control a plant or animal (or its products) that has become a pest (Carver, 1989).

Predators, parasitoids, fungi and other beneficial organisms can be used for the bio-control of insect pests. The fungus $V$. lecanii is one of several Deuteromycetes species that can be used for crop protection. This work is a review of the international literature related to $V$. lecanii for the bio-control of insects of agricultural importance.

\section{Biology and Ecology of Verticillium lecanii}

V. lecanii lacks a sexual phase (perfect stage) and reproduces by means of non-motile, asexual spores called conidia. Germination of these conidia produces hyphae and after subsequent growth, these hyphae produce conidiophores which finally produce conidia (Alexopoulos \& Mims, 1979). V. lecanii is able to grow on both living and dead materials
(Schuler, 1991). It is non-fastidious and can grow on all conventional mycological media so far tested, e.g. CzapeckDox, Malt extract, Sabouraud and Potato dextrose agars, including a media containing chitin as the sole source of carbon and nitrogen. It has capability to produce conidia on solid media; in contrast, $V$. lecanii assumes a semi-yeast morphology in liquid media (Hall, 1981a).

$V$. lecanii is one of the most common and important entomophagous Hyphomycetes fungi occurred on coccids, aphids, thrips, Diptera, Homoptera, Hymenoptera, Lepidoptera and mites and in all the climatic regions. Other important substrates for $V$. lecanii are rusts and other fungi. It is a consequence of this habit that the species is frequently isolated from soil; it has also been isolated from leaf litter of oak, ash and birch, tea leaves, barley seed, baker's yeast, beet seed and bursting corn kernels (Domsch et al., 1980; Sewify \& Mabrouk, 1990; Andreeva \& Chternchis, 1995). During greenhouse experiment, V. lecanii could control the cucumber powdery mildew (Sphaerotheca fuliginea), keeping the mildew severity with partially resistant cucumber variety, below $15 \%$ of infected leaf area or under economic threshold (Verhaar et al., 1993; Verhaar et al., 1996). Transmission electron microscopy observations have provided evidence that $V$. lecanii has also potential to colonize mycelial structures of Sphearotheca fuliginea and reduced the pathogenicity of this phytopathogenic fungus under laboratory conditions (Askary et al., 1997; Askary et al., 1998). Isolates of V. lecanii readily isolated from coffee rust lesions under laboratory conditions and at high relative air humidity, showed hyperparasitic and antibiotic properties. Other isolates of $V$. lecanii of insect origin were also able to parasitise Hemileia vastatrix (Eskes et al., 1991).

The parasitism of $V$. lecanii has been well demonstrated against many other phytopathogenic fungi like Puccinia graminis var. tritici (Hänssler et al., 1981), Puccinia striiformis (Mendgen, 1981), Uromyces appendiculatus (Grabski \& Mendgen, 1985; Grabski \& Mendgen, 1986), Phaeoisariopsis personata and Puccinia arachidis (Ghewande, 1989; Ghewande, 1990; Zambettakis et al., 1985), Uncinula necator (Heintz \& Blaich, 1990), Puccinia horiana (Srivastava et al., 1985; Whipps, 1993); Puccinia coronata (Leinhos \& Buchenauer, 1992) and Puccinia allii (Uma \& Taylor, 1987).

This fungus also occurs on several species of Nematodes (Schuler, 1991). The parasitism of $V$. lecanii on cysts or eggs of several nematode species has been well reported (Hänssler, 1990; Uziel and Sikora, 1992; Meyer et al., 1990). The cyst wall of Heterodera schachtii was penetrated by $V$. lecani mycelium only after 60 hours of inoculation. Inside the cyst cavity, the fungus passed through the eggshells and colonized the larvae. V. lecanii secreted specific enzymes into the culture medium which enable him to degrade constituents of the cyst as well as the eggshell (Hänssler, 1990). Wild or mutant strains of $V$. lecanii showed efficacy against nematodes under greenhouse conditions (Meyer \& Meyer, 1995; Meyer \& 
Meyer, 1996; Meyer, 1994; Reddy et al., 1996; Meyer \& Huettel, 1996; Meyer et al., 1997). Like all the other entomopathogenic fungi, $V$. lecanii infects its invertebrate hosts through the external cuticle. Three phases have been recognised in the development of insect mycosis: adhesion and germination of the fungal spores on the host cuticle, penetration of the insect integument by a germ tube, and development of the fungus inside the insect body, generally resulting in death of the infected host. Under good humidity conditions, the dead host is covered by the fungal spores and hyphae (Quinlan, 1988; Zimmermann, 1984).

Humidity and temperature are the most important climatic factors which influence the growth of $V$. lecanii (Schuler, 1991). Virtually, all fungi require high humidity for spore germination, growth and sporulation. $V$. lecanii conidia require high humidity to germinate and possibly do so in water film only (Hall, 1981a). The optimal temperature requirement for spore germination and colony growth or infection may vary from isolate to isolate, between $15^{\circ} \mathrm{C}$ and $25^{\circ} \mathrm{C}$ (Hall, 1981a; Ekbom, 1979; Easwaramoorthy \& Jayaraj, 1977; Barson, 1976; Hirte et al., 1989; Sermann et al., 1991; Hsiao et al., 1992). At $5^{\circ} \mathrm{C}$, spores of $V$. lecanii can germinate and grow slowly and above $30^{\circ} \mathrm{C}$ its germination and growth may cease.

\section{Insecticidal potential of $V$. lecanii}

The fungus appears to have been first observed in Ceylon (Sri Lanka) about 1861, on diseased Lecanium coffeae. It was subsequentely found by Zimmermann on Lecanium viride on coffee, in Java (Indonesia) and was briefly described by him under the name Cephalosporium lecanii, in a short paper in 1898. Zimmermann stated that each dead scale was surrounded by a white fungus. He cultivated the fungus on nutrient agar and directed attention to the possibility that this fungus can be utilised for controlling the scale-insect (Petch, 1925).

Guegnen published an exhaustive work in 1905 on fungusparasites of man and animals, and reported a new conidial form, Acrostalagmus coccidicola, found by him on coccid in a greenhouse in Paris (Parkin, 1906). Guegnen cultivated this fungus on several media and described it. He attempted to infect an undetermined coccid by applying the fungal spores to the insect with a brush, but without success. According to the description, Acrostalagmus coccidicola does not differ morphologically from Cephalosporium lecanii (Petch, 1925). In 1905, Dop published a paper on a new fungus parasite of Aspidiotus from Martinique; he stated that the advent of the fungus has practically saved the cocoanut palm cultivation in this Island; the fungus was referred to the genus Hyalopus; thus, it is probably near akin to Cephalosporium (Parkin, 1906).

Parkin (1906) reported fungus similar to Cephalosporium lecanii from Ceylon on lecanium viride, L. hemisphaericum and $L$. nigrum and stated that the ease whereby the fungi can be artificially cultivated is a point in their favour for their possible use for controlling the scale-insects. Successful infection of the green-bug (Lecanium viride) on the Java coffee by an artificial culture of Cephalosporium was then cited by him. At that time, conditions for successful inoculation were therefore somewhat obscure. In 1909, information with regard to the distribution and effectiveness of insect-pathogenic fungus in the West Indian Islands has been collected by various researchers (South, 1910). The fungi which were commonly reported by these researchers are: the white-headed fungus (Ophionectria coccicola E. and E.), the black fungus (Myriangium duriaci Mont.), the shield scale fungus (probably Cephalosporium lecanii Zimm) (South, 1910).

In some districts of these islands where the general conditions are favourable to their growth, the parasites of certain species of insects exist naturally in large numbers and were responsible for the comparative rarity of these species in those districts (South, 1910). Work was carried out in order to introduce the parasite into places in which the conditions are favourable to its growth, but in which it has not previously been known to occur and to produce it where possible by artificial means.

Methods of introducing these fungi include spraying the spores and portions of the mycelium of the fungi onto trees which it is intended to infect, tying infected material into trees which it is desired to infect and finally, planting among the trees to be infected, small trees whose foliage is well infected with various parasitic scale fungi, so that the leaves of the small trees come into contact with those of the larger ones. With regard to the artificial formation of conditions suitable to these fungi in localities where they are naturally unfavourable, two methods were suggested: spraying trees with clean water, once or twice a week and allowing the trees attacked by scale insects to become covered with a fairly thick growth of Bengal beans (Mucuna pruriens); the beans were supposed to create damp conditions.

The results with Cephalosporium lecanii and another fungus were said to be encouraging (South, 1910). Petch (1925) collected specimens of insect pathogenic fungi from several localities and cultivated them on nutritive media for further study and reported that most of the insect pathogenic fungi showed similarity with Cephalosporium lecanii.

$V$. lecanii has been employed in Brazil for controlling the green scale of coffee by Viegas who gave him in 1939, its current name (Schuler, 1991). Gams (1971), after cultural and morphological examination of type specimens, regarded the identifying characteristics of previously determined Cephalosporium as well as other associated species insufficient to justify their separation as distinct species; he, therefore, proposed that all these species should be amalgamated as synonyms of Verticillium lecanii. This fungus has never been implicated, in temperate climates in epizootics, although it is frequently isolated from individual insects (Barson, 1976; Hall, 1981a). 
Indoors, in the somewhat tropical environment of greenhouses, in North Europe and USA, it frequently decimates populations of scales and aphids, e. g. $100 \%$ mortality of several target insects was reported in limited trials (Hall, 1981a).

The potential of the fungus has been realised in glasshouse systems in Europe thanks to the extensive research in U. K., in years 70 . For that, laboratory methods for obtaining uniform batches of conidiospores and stock insects have been developed together with a bio-assay technique, using isolated apterous insects on leaf discs, in order to quantify accurately the pathogenicity of $V$. lecanii conidiospores against aphids. A single spore isolate of $V$. lecanii obtained from a diseased aphid Macrosiphoniella sanborni infesting chrysanthemums was therefore cultured on Sabouraud dextrose agar and spore concentration was determined using improved hemacytometer. The bio-assay technique consists in treating artificially reared aphids with the fungal spore on filter paper in Buchner funnel, by pouring gently a known amount of the appropriate spore suspension on them. After treatment, aphids were singly placed on leaf discs in high humidity assay cells which were kept in perplex cages at high humidity for the duration of the experiment (Hall, 1976). This assay technique provides a good measurement of the pathogenicity of batches of conidiospores of $V$. lecanii.

Once the efficacy of the pathogen proved under laboratory, it has been tested on aphid-infested Chrysantemum plants in greenhouse. These plants were sprayed with conidial suspension with pneumatic hand sprayer (Hall, 1979; Hall \& Burges, 1979). All these laboratory and greenhouse experiments led to the development of two commercial products "Vertalec" and "Mycotal" based on strains specifically selected for use against aphids and whiteflies (Gardner et al., 1984; Ramakers, 1989). V. lecanii has been tested experimentally against a range of pests, in a number of countries, with varying results which were said in general to be encouraging (Kitazawa et al., 1984; Helyer \& Wardlow, 1987; Saito, 1988; Gour \& Dabi, 1988; Gopalokrishnan, 1989; Ravensberg et al., 1990a; Ravensberg et al., 1990 b; Byrne, 1991; Van der Schaaf et al., 1991; Meade \& Byrne, 1991; Masuda \& Kikuchi, 1992; Pinna, 1992; Chandler et al., 1993; Zukauskiene \& Sirvinskas, 1993; Helyer, 1993; Ravensberg et al. 1994; Miranpuri and Khachatourians, 1994; Fournier, 2000; Gindin et al., 2000; Wang et al., 2004; Nirmala et al., 2006; Liande et al., 2007; Jeong et al., 2007; Van et al., 2007; Goettel et al., 2008; Jeong et al., 2008; Chavan et al., 2008; Shinya et al., 2008).

The effectiveness of this bio-control agent has been proved also in soil against the soilborne stages of the western flower thrips (Frankliniella occidentalis) (Hirte et al., 1994; Sermann et al., 1994; Sermann et al. 1996; Beyer et al., 1997a; Beyer et al., 1997b). Nevertheless, despite the fact that greenhouses offer an attractive environment for the exploitation of the fungus, the effectiveness of $V$. lecanii still depends on high humidity and selection of strains infecting the host rapidly or investigation of methods able to favour the fungus action is essential.

The effects of pesticides on spores germination, mycelial growth and sporulation as well as on infection have been investigated quantitatively and qualitatively with strains of $V$. lecanii. Some chemicals were shown to be incompatible while others proved relatively harmless to the fungus (Hall, 1981b; Khalil et al., 1985; Saito \& Yabuta, 1996). Synergistic inhibitory action of innocuous chemicals on conidiospores germination of the pathogen has been reported. On the basis of all these studies, it is concluded that a careful selection of pesticides and fungicides would permit the combined use of $V$. lecanii and chemicals in integrated control programmes (Hall, 1983).

Similarly, the combined use of V. lecanii with other biological control agents such as the whitefly parasites Encarsia formosa, Amblyseius spp. and other pests antagonists has been investigated (Kanagaratnam et al., 1979; Bennison et al., 1990; Van der Schaaf et al., 1991; Buxton \& Wardlow, 1992). Results showed that integration of $V$. lecanii with these biocontrol agents is also possible.

The virulence of two strains of $V$. lecanii originally isolated respectively from the aphid Myzus persicae and whitefly (Trialeurodes vaporariorum) was bioassayed against 3 different aphids' species. These strains (V24 and V18) were capable of infecting all three aphids species, but their virulence determined by $\mathrm{LC}_{50}$ and $\mathrm{LT}_{50}$ varied. The strain (V24) isolated from $M$. persicae showed the highest virulence against the homologous aphid species, but the whitefly derived strain (V18) showed also the highest virulence against one of the aphid species.

The variability of the bioassay results and the impossibility of defining clearly traits associated with the virulence of a fungus strain toward a specific insect species have been discussed and spores improvement using adjuvants was suggested (Alavo et al, 2002a). However, greenhouse trials aimed at controlling $M$. persicae in chinese cabbage using $V$. lecanii blastospore suspension either pure or with adjuvants such as soyflour and rape oil were discouraging; the product failed to control the aphid populations (Alavo et al, 2002b). Some other adjuvants were said to improve germination and infection rate of $V$. lecanii; nevertheless, effective pest control using $V$. lecanii conidia suspension combined with such additives was not demonstrated (Jin et al., 2006; Zhangyan et al. 2006). Fluorescent microscopy investigations revealed almost 100\% spore loss from the cuticle of aphid larvae before infection. Spore loss was attributed to the rapid moulting of aphids larvae and the unreliable control of aphids using $V$. lecanii was discussed (Alavo et al, 2002b; Alavo, 2000).

Nowadays, a formulation of $V$. lecanii is commercialized under the name of 'Mycotal ${ }^{\circledR}$ ' only for use against Whitefly larvae. This product efficacy is said to be improved if applied together 
with adjuvant based on emulsifiable vegetable oil (Koppert, 2015).

\section{Conflict of interest}

Authors would hereby like to declare that there is no conflict of interests that could possibly arise.

\section{References}

Alavo TBC, Sermann H, Bochow H (2002a) Virulence of strains of the entomopathogenic fungus Verticillium lecanii to aphids: Strain improvement. Archives of Phytopathology and Plant Protection 34(6):379-398.

Alavo TBC, Sermann H, Bochow H (2002b) Biocontrol of aphids using Verticillium lecanii in greenhouse: Factor reducing the effectiveness of the entomopathogenic fungus. Archives of Phytopathology and Plant Protection 34(6):407424.

Alavo TBC (2000) Investigations on the entomopathogenic fungus Verticillium lecanii (Zimm.) Viegas (Moniliaceae, Hyphomycetes) for the biological control of aphids (Aphididae, Homoptera). ISBN 3-89574-394-1. Verlag Dr. Koester Berlin. 101 pages.

Alexopoulos CJ, Mims CW (1979) Introductory Mycology, Third edition John Wiley and Sons, 632 p.

Andreeva IV, Chternchis MV (1995) Microbiologitcheskie preparati protif pautinovo klesha v tiplitsah. Zashita Rastenii 11: 41-42.

Askary H, Benhamou N, Brodeur J (1997) Ultrastructural and Cytochemical Investigations of the Antagonistic Effect of Verticillium lecanii on Cucumber Powdery Mildew. Phytopathology 87:359-368.

Askary H, Carriere Y, Belanger RR, Brodeur J (1998) Pathogenicity of the Fungus Verticillium lecanii to Aphids and Powdery Mildew. Biocontrol Science and Technology 8: 2332.

Barson G (1976) Laboratory studies on the fungus Verticillium lecanii, a larval pathogen of the large elm bark beetle (Scolytus scolytus). Annals of Applied Biology 83: 207-214.

Beyer PU, Hirte WF, Sermann H (1997a) The behaviour of the entomopathogenic fungus Verticillium lecanii (Zimm.)Viegas in soil; I. Viability in soil at different ecological conditions. Zeitschrift für Pflanzenkrankheiten und Pflanzenschutz 104 (1): 54-64.

Beyer PU, Hirte WF, Sermann H (1997b) The behaviour of the entomopathogenic fungus Verticillium lecanii (Zimm.)Viegas in soil; II. Longevity of V. lecanii in soil and mineral wool and the optimization of its survival by addition of promoting organic substances. Zeitschrift für Pflanzenkrankheiten und Pflanzenschutz 104 (1): 65-74.

Bennison JA, Hockland S, Jacobson R (1990) Recent developments with integrated control of Thrips on cucumber in the United Kingdom. SROP / WPRS Bull. XIII /5: 19-26.

Buxton J, Wardlow L (1992) Two years of trials with biological control programmes in all-year-round chrysanthemums. Bulletin OEPP / EPPO 22: 503-511.

Carver M (1989) Biological Control of Aphids. In: Minks AK, Harrewijn P (eds.) World Crop Pests (Editor in Chief: Helle W.); Aphids, Their Biology, Natural enemies and Control 2C, 141-166.

Chandler D, Heale JB, Gillespie AT (1993) Competitive interaction between strains of Verticillium lecanii on two insect hosts. Annals of Applied Biology 122: 435-440.

Chavan BP, Kadam JR, Saindane YS (2008) Bioefficacy of liquid formulation of Verticillium lecanii against aphid (Aphis gossypii). International Journal of Plant Protection 1(2): 6972.

Devonshire AL (1989) Resistance of Aphids to Insecticides. In: Minks AK, Harrewijn P (Eds) World Crop Pests (Editor in Chief: Helle W.); Aphids, Their Biology, Natural enemies and Control (eds.) 2C: 123-140.

Domsch KH, Gams W, Anderson TH (1980) Compendium of Soil Fungi. Vol. 1 Academic Press; 859 p.

Easwaramoorthy S, Jayaraj S (1977) The Effect of Temperature, $\mathrm{pH}$ and Media on the growth of the Fungus Cephalosporium lecanii. Journal of Invertebrate Pathology 29: 399-400.

Ekbom BS (1979) Investigations on the Potential of a Parasitic Fungus (Verticillium lecanii) for Biological Control of the greenhouse Whitefly (Trialeurodes vaporariorum). Swedish Journal of Agricultural Research 9: 129-138.

Eskes AB, Mendes MDL, Robbs CF (1991) Laboratory and field studies on parasitism of Hemileia vastatrix with Verticillium lecanii and V. leptobactrum. Café Cacao Thé 35 (4): 275-282.

FAO (1989) The State of Food and Agriculture. (World and regional reviews, Financing agricultural development). 69-70.

Gams W (1971) Cephalosporium-artige Schimmelpilze (Hyphomycetes).VEB Gustav Fischer Verlag Jena; 262 p.

Gardner WA, Oetting RD, Storey GK (1984) Scheduling of Verticillium lecanii and Benomyl Applications to Maintain Aphid (Homoptera: Aphididae) Control on Chrysanthemums 
in Greenhouses. Journal of Economic Entomology 77: 514518 .

Ghewande MP (1989) Biological control of late leaf-spot (Phaeoisariopsis personata) of groundnut (Arachis hypogaea). Indian Journal of Agricultural Sciences 59 (3): 189-190.

Ghewande MP (1990) Biological control of groundnut (Arachis hypogaea L.) rust (Puccinia arachidis Speg.) in India. Tropical Pest Management 36 (1): 17-20.

Gindin G, Geschtovt NU, Raccah B, Barash I (2000) Pathogenicity of Verticillium lecanii to different developmental stages of the silverleaf whitefly, Bemisia argentifolii. Phytoparasitica 28(3): 229-239.

Goettel MS, Koike M, Jeong JK, Daigo A, Ryoji S, Brodeur J (2008) Potential of Lecanicillium spp. for management of insects, nematodes and plant diseases. Journal of Invertebrate Pathology 98(3): 256-261

Gour HN, Dabi RK (1988) Biological control of white grub using Verticillium lecanii (Zimmerm.) Viegas. Current Science 57(11): 620-621.

Grabski GC, Mendgen K (1985) Einsatz von V. lecanii als biologisches Schädlingsbekämpfungsmittel gegen den Bohnenrostpilz $U$. appendiculatus var. appendiculatus im Feld und im Gewächshaus. Phytopathologische Zeitschrift 113: 243-251.

Grabski GC, Mendgen K (1986) Die Parasitierung des Bohnenrostes Uromyces appendiculatus var. Appendiculatus durch den Hyperparasiten Verticillium lecanii: Untersuchungen zur Wirt-Erkennung, Penetration und Abbau der Rostpilzsporen. Journal of Phytopathology 115; 116-123.

Hall RA (1976) A Bioassay of the Pathogenicity of Verticillium lecanii Conidiospores on the Aphid, Macrosiphoniella sanborni. Journal of Invertebrate Pathology 27: 41-48.

Hall RA (1979) Pathogenicity of Verticillium lecanii conidia and blastospores against the aphid, Macrosiphoniella sanborni. Entomophaga 24(2): 191-198.

Hall RA, Burges HD (1979) Control of aphids in glasshouses with the fungus, Verticillium lecanii. Annals of Applied Biology 93; 235-246.

Hall RA (1981a) The Fungus Verticillium lecanii as a Microbial Insecticide against Aphids and Scales. In: Burges HD (Editor) Microbial Control of Pests and Plant Diseases 1970-1980; Academic Press; 483-498.

Hall RA (1981b) Laboratory studies on the effects of fungicides, acaricides and insecticides on the entomopathogenic fungus, Verticillium lecanii. Entomologia Experimentalis et Applicata 29: 39-48.

Hall RA (1983) Synergistic Inhibitory Action of Preparations of Iprodione and Carbaryl on Germination of conidia of Verticillium lecanii. Journal of Invertebrate Pathology 42: 384386.

Hänssler G, Knörzer M, Reisener HJ (1981) Lichmikroskopische Untersuchungen der Interaktion zwischen Puccinia graminis var. tritici und Verticillium lecanii. Phytopathologische Zeitschift, 102; 310-319.

Hänssler G (1990) Verticillium lecanii als Parasit an Cysten von Heterodera schachtii. Zeitschrift für Pflanzenkrankheiten und Pflanzenschutz 97(2): 194-201.

Helyer NL, Wardlow LR (1987) Aphid control on chrysanthemum using frequent, low dose applications of Verticillium lecanii. Bulletin SROP X(2): 62-65.

Helyer N (1993) Verticillium lecanii for control of aphids and thrips on cucumber. Bulletin OILB srop 16 (1): 63-66.

Heintz C, Blaich R (1990) Verticillium lecanii als Hyperparasit des Rebmehltaus (Uncinula necator). Vitis 29: 229-232.

Hirte WF, Walter C, Grünberg M, Sermann H, Adam H (1989) Selektion von Pathotypen von Verticillium lecanii für verschiedene tierische Schaderreger in Gewächshauskulturen und Aspekte der biotechnologischen Massensporenproduktion. Zentralblatt fur Mikrobiologie 144: 405-420.

Hirte W, Triltsch H, Sermann H (1994) Growth and surviability of the entomopathogenic fungus Verticillium lecanii in the soil. Bulletin OILB srop 17(3): 226-229.

Hsiao WF, Bidochka MJ, Khachatourians GG (1992) Effect of temperature and relative humidity on the virulence of the entomopathogenic fungus, Verticillium lecanii, toward the oatbird berry aphid, Rhopalosiphum padi (Hom., Aphididae). Journal of Applied Entomology 114: 484-490.

Jeong JK, Goettel MS, Gillespie DR (2007) Potential of Lecanicillium species for dual microbial control of aphids and the cucumber powdery mildew fungus, Sphaerotheca fuliginea . Biological Control 40 (3): 327-332.

Jeong JK, Goettel MS, Gillespie DR (2008) Evaluation of Lecanicillium longisporum, Vertalec ${ }^{\circledR}$ for simultaneous suppression of cotton aphid, Aphis gossypii, and cucumber powdery mildew, Sphaerotheca fuliginea, on potted cucumbers. Biological Control 45(3): 404-409

Jin YL, Seong WK, Cheol SY, Jeong JK, Dong RC, Seung WK (2006) Verticillium lecanii Spore Formulation Using UV Protectant and Wetting Agent and the Biocontrol of Cotton Aphids. Biotechnology Letters 28 (13): 1041-1045. 
Kanagaratnam P, Burges HD, Hall RA (1979) Integration of Verticillium lecanii and Encarsia formosa for whitefly control. Annual Report, The Glasshouse Crops Research Institute Rustington Littlehampton.

Khalil SK, Shah MA, Naeem M (1985) Laboratory studies on the compatibility of the entomopathogenic fungus Verticillium lecanii with certain pesticides. Agriculture, Ecosystems and Environment 13: 329-334.

Kitazawa K, Fujisawa I, Imabayashi SI (1984) Isolation of Verticillium lecanii (Zimm.) Viegas Affecting Aphids and Greenhouse Whitefly in Japan. Annals of Phytopathological Society of Japan 50: 574-581.

Koppert BV (2015) Mycotal: Verticillium lecanii-m. http://www.koppert.com. Consulted on 29/04/2015.

Leinhos GME, Buchenauer H (1992) Hyperparasitism of selected fungi on rust fungi of cereal. Zeitschrift für Pflanzenkrankheiten und Pflanzenschutz 99(5): 482-498.

Liande W, Jian H, Minsheng Y, Xiong G, Bo L (2007) Toxicity and feeding deterrence of crude toxin extracts of Lecanicillium (Verticillium) lecanii (Hyphomycetes) against sweet potato whitefly,Bemisia tabaci (Homoptera: Aleyrodidae). Pest Management Science 63(4): 381-387

Masuda T, Kikuchi O (1992) Pathogenicity of Verticillium lecanii Isolates to Whitefly and Aphids. Japanese Journal of Applied Entomology and Zoology 36: 239-245.

Meyer SLF, Huettel RN, Sayre RM (1990) Isolation of fungi from Heterodera glycines and in vitro bioassays for their antagonism to eggs. Journal of Nematology 22(4): 532-537.

Meyer SLF (1994) Effects of a wild type strain and a mutant strain of the fungus Verticillium lecanii on Meloidogyne incognita populations in greenhouse studies. Fundamental and applied Nematology 17(6): 563-567.

Meyer SLF, Meyer RJ (1995) Effects of mutant strain and a wild type strain of Verticillium lecanii on Heterodera glycines

populations in the greenhouse. Journal of Nematology 27(3): 409-417.

Meyer SLF, Meyer RJ (1996) Greenhouse studies comparing strains of the fungus Verticillium lecanii for activity against the nematode Heterodera glycines. Fundamental and applied Nematology 19(3): 305-308.

Meyer SLF, Huettel RN (1996) Application of a sex pheromone, pheromone analogs, and Verticillium lecanii for management of Heterodera glycines. Journal of Nematology 28(1): 36-42.
Meyer SLF, Johnson G, Dimock M, Fahey JW, Huettel RN (1997) Field efficacy of Verticillium lecanii, sex pheromone, and pheromone analogs as potential management agents for soybean cyst nematode. Journal of Nematology 29(3): 282288.

Meade DL, Byrne DN (1991) The Use of Verticillium lecanii against Subimaginal Instars of Bemisia tabaci. Journal of Invertebrate Pathology 57: 296-298.

Mendgen K (1981) Growth of Verticillium lecanii in Pustules of Stripe rust (Puccinia striiformis). Phytopathologische Zeitschrift 102: 301-309.

Miranpuri GS, Khachatourians GG (1994) Pathogenicity of Beauveria bassiana (Bals.) Vuill. and Verticillium lecanii (Zimm.) toward blister beetle, Lytta nuttali Say (Col., Meloidae). Journal of Applied Entomology 118: 103-110.

Nirmala R , Ramanujam B, Rabindra RJ, Rao NS (2006) Effect of entomofungal pathogens on mortality of three aphid species. Journal of Biological Control 20(1):89-94.

Parkin J (1906) Fungi parasitic upon Scale-Insects (Coccidae and Aleurodidae): a general account with special reference to Ceylon Forms. Annals of the Royal Botanic Gardens, Peradeniya 3: 11-82.

Petch T (1925) Studies in entomogenous fungi. Transactions of British Mycological Society 152-182.

Pinna M (1992) Impiego di Verticillium lecanii (Zimm.) per il controllo biologico di Aphis gossypii (Glover) su cetriolo in coltura protetta. Informatore Fitopatologico 10: 56-58.

Quinlan RJ (1988) Use of fungi to control insects in glasshouses. In Burge M. N. (editor) Fungi in biological control systems. Manchester University Press 19-85.

Ramakers PMJ (1989) Biological Control in Greenhouses. In World Crop Pests (Editor in Chief: Helle W.); Aphids, Their Biology, Natural enemies and Control (eds. Minks A. K., Harrewijn P.) Vol.2C; 199-208.

Ravensberg WJ, Malais M, Van der Schaaf DA (1990a) Applications of Verticillium lecanii in tomatoes and cucumbers to control whitefly and thrips. SROP / WPRS Bulletin 13 (5): 173-178.

Ravensberg WJ, Malais M, Van der Schaaf DA (1990b) Verticillium lecanii as a microbial insecticide against glasshouse whitefly. Brighton Crop Protection ConferencePests and Diseases 1: 265.

Ravensberg WJ, Van Buysen AC, Berns R (1994) Side-effects of pesticides on Verticillium lecanii: in vivo tests on whitefly and aphids. Bulletin OILB / SROP 17(3): 234-238. 
Reddy PP, Rao MS, Nagesh M (1996) Management of the citrus nematode on acid lime by integration of parasitic fungi and oil cakes. Pest Management in Horticultural Ecosystems 2(1): 15-18.

Saito T (1988) Control of Aphis gossypii in greenhouses by a Mycoinsecticidal Preparation of Verticillium lecanii and Effect of Chemicals on the fungus. Japan Journal of Applied Entomology and Zoology 32: 224-227.

Saito T, Yabuta M (1996) Laboratory studies on Effect of Pesticides on Entomopathogenic Fungus, Verticillium lecanii. Japan Journal of Applied Entomology and Zoology 40: 71-76.

Schepers A (1989) Chemical control of Aphids. In: Minks AK, Harrewijn P (Eds.) World Crop Pests (Editor in Chief: Helle W.); Aphids, Their Biology, Natural enemies and Control Vol.2C; 89-122.

Schuler T (1991) Verticillium lecanii (Zimmermann) Viegas (Hyphomycetales: Moniliaceae): Geschichte, Systematik, Verbreitung, Biologie und Anwendung im Pflanzenschutz. Mitteilungen aus der Biologischen Bundesanstalt für Land $u$. Forstwirtschaft, Berlin-Dahlem. Heft 269:154.

Sermann H, Wick M, Hirte W (1991) Control of aphids and thrips with Verticillium lecanii. Bulletin OILB / SROP XIV(7): 140-141.

Sermann H, Kästner U, Hirte W (1994) Effectiveness of a soil application of Verticillium lecanii on soilborne stages of Frankliniella occidentalis. Bulletin OILB / SROP 17(3) 230233.

Sermann H, Beyer U, Hirte W (1996) Langzeitwirkung einer Bodenapplikation von Verticillium lecanii gegenüber dem Kalifornischen Blütenthrips Frankliniella occidentalis. Mitteilungen aus der BBA, Heft 321: 476.

Sewify GH, Mabrouk AM (1990) The susceptibility of different stages of citrus brown mite Eutetranychus orientalis Oudemans (family: Tetranychidae) to entomopathogenic

fungus Verticillium lecanii. Proceedings and abstracts, Vth International Colloquium on Invertebrate Pathology and Microbial Control, Adelaide, Australia, 20-24 August 1990: 395.

Shinya R, Aiuchi D, Kushida A, Tani M, Kuramochi K, Koike M (2008) Effects of fungal culture filtrates of Verticillium lecanii (Lecanicilliumspp.) hybrid strains on Heterodera glycines eggs and juveniles. Journal of Invertebrate Pathology 97(3):291-297.

South FW (1910) The control of scale insects in the British West Indies by means of Fungoid parasites. West Indian Bulletin XI: 1-80.
Srivastava AK, Defago G, Kern H (1985) Hyperparasitism of Puccinia horiana and other Microcyclic Rusts. Phytopathologische Zeitschrift 114: 73-78.

Uma NU, Taylor GS (1987) Parasitism of leek rust urediniospores by four fungi. Transactions of British Mycological Society 88(3): 335-340.

Uziel A, Sikora RA (1992) Use of non-target isolates of the entomopathogen Verticillium lecanii (Zimm.) Viegas to control the potato cyst nematode, Globodera pallida (Stone). Nematologica 38(1): 123-130.

Van der Schaaf DA, Ravensberg WJ, Malais M (1991) Verticillium lecanii as a microbial insecticide against whitefly. Bulletin OILB / SROP XIV(7): 120-129.

Van HV, Suk IH, Keun K. 2007. Selection of Entomopathogenic Fungi for Aphid Control. Journal of Bioscience and Bioengineering 104(6):498-505.

Verhaar MA, Van Strien PAC, Hijwegen T (1993) Biological control of Cucumber Powdery Mildew (Sphaerotheca fuliginea) by Verticillium lecanii and Sporothrix $c f$. Flocculosa. Bulletin OILB / SROP 16(11): 79- 81.

Verhaar MA, Hijwegen T, Zadoks JC (1996) Glasshouse Experiments on Biocontrol of Cucumber Powdery Mildew (Sphaerotheca fuliginea) by the Mycoparasites Verticillium lecanii and Sporothrix rugulosa. Biological Control 6: 353360 .

Wang L, Huang J, You M and Liu B (2004) Time-dosemortality modelling and virulence indices for six strains ofVerticillium lecanii against sweetpotato whitefly, Bemisia tabaci (Gennadius). Journal of Applied Entomology 128 (7): 494-500.

Whipps JM (1993) A review of white rust (Puccinia horiana Henn.) disease on chrysanthemum and the potential for its biological control with Verticillium lecanii (Zimm.) Viegas. Annals of Applied Biology 122: 173-187.

Zambettakis C, Sankara P, Metivier A (1985) Darluca filum, Tuberculina costaricana et Verticillium lecanii, Hyperparasites de Puccinia arachidis, considérés comme éléments d'une lutte intégrée. Bulletin de la Société de Mycologie de France tome 101 fascicule 2: 165-181.

Zhangyan Shi, Mei Li \& Long Zhang. 2006. Effects of nutrients on germination of Verticillium lecanii (=Lecanicillium sp.) conidia and infection of greenhouse whitefly, (Trialeurodes vaporariorum). Biocontrol Science and Technology 16(6):599-606. 
Zimmermann G (1984) Pilze zur biologischen Bekämpfung von Blattläusen. Gärtnerbörse und Gartenwelt 17: 406-407.

Zukauskiene J, Sirvinskas J (1993) Interrelations of populations of phytophagous insects and entomopathogenic species Verticillium lecanii in greenhouses. Acta Entomologica Lituanica 11: 120. 